CHAPTER 18

\title{
Ungoverned or Alternatively Governed Spaces in North-Eastern Nigeria
}

\author{
A Critical Exploration of Boko Haram's Ideological Motif
}

\author{
Benson O. Igboin
}

\section{Introduction}

The whole question of what was happening to us, which is now called Boko Haram, has never been subjected to any critical intellectual analysis. We've just been interested in the burning of houses, suicide bombers and so on, but we have never attempted to ask what is the moral economy or what really predisposes people to this kind of attitude, where did this come from? Beyond thinking of intelligence as gathering gossip and information from people, there are intellectual views. It is possible to trace the historical processes that have produced what we have now in the name of Boko Haram. Is there any connection between Boko Haram and other forms of violent protests that precede it, whether it's Maitatsine or whatever? Can we explain why this Boko Haram is dominant in Maiduguri, Yobe and not Sokoto or Kebbi? These are questions that only intellectual analyses, dispassionate, taken away from politics, can help us to come to the conclusion because there must be a reason and it may be sociological, cultural, religious or historical, as to why certain things happen where they do. If this was about religion, and Muslims are trying to expand the frontiers of Islam, which kind of a stupid man will be fighting inside his own house and hope to conquer other people?

KUKAH 2O13: 39-4O

Matthew H. Kukah, the Catholic Bishop of Sokoto, has been one of the few dispassionate and committed crusaders of good governance in Nigeria. His averments above provide a template for undertaking an in-depth historical and ideological analysis of Boko Haram, a group which by 2015 was declared by the Global Terrorism Index as the most deadly terrorist group in the world, followed by the Islamic State of Iraq and Syria (ISIS), on the basis of their capacities for actual violence (Botha, Ewi, Salifu, and Abdile 2017). Many media outfits, governments at both national and transnational levels, and commentators and 
scholars have been more interested in the outward manifestations or operations of Boko Haram and military counter operations, while leaving the historical trajectory that underlined the ideological anchorage of the group. While efforts geared towards counter-terrorism are salutary for their immediate effects, they do not, as the Nigerian experience has shown, address the fundamental inspiration that results in collective violence again and again. Kukah is therefore challenging us to go beyond the politics, politicisation, and economical factors that are often adduced for the rise of the group and engage in a more nuanced historical and ideological investigation to unravel the remote factors that have made northern Nigeria a hotbed of inveterate violence.

Kukah's reference to Sokoto and Kebbi in the North-western geo-political zone is instructive because at the time of the rise of Boko Haram, Sokoto and Kebbi states were the poorest of all the 36 states of Nigeria (The National Bureau of Statistics 2005). In other words, if poverty is actually the cause of the rise of Boko Haram, as the West widely believed and theorised (Ini 2013; Ayegba 2015), the states of Sokoto and Kebbi should have been the proper provenance. In addition, studies have shown that even though Sokoto and Kebbi are extremely poor, they are the most peaceful in the North coming behind only Jigawa state (Obinna-Esiowu 2018). Zamfara state, where sharîa was instituted in 1999 as Nigeria returned to civil rule, is now one of the states being devastated by bandits. Studies have shown that poverty cannot always be connected to violence or insurgency, especially when religious nationalistic ideology, collective hatred, or moral conviction are involved (Mandel 2002; Yanay 2002; Skitka and Mullen 2002; Ogunfolu, Assim and Adejumo 2018: 19o). Furthering this argument, Christopher Smith, reporting to the US House of Representatives Committee on Foreign Affairs, pointedly notes:

I think it is all too convenient to suggest that somehow just because there are deprivations, somehow people then automatically know Osama bin Laden was rich. Ideology that is highly, highly radicalised may exploit poverty at times, but poor people don't necessarily become terrorists and killers. That is an insult, frankly, to poor people. I think we made the same mistake, with all due respect, with South Sudan.

"US Policy Toward Nigeria" 2012: 32

Thus, Kukah's last question above is germane in an attempt to underscore the ultra-jihädi-Salafism that defines the ideological bent of the group, which has a long history stretching back to pre-colonial era. Of course, by fighting inside its house, Boko Haram is contesting space with the government of Nigeria with the aim to institute its own kind of rule and form of Islam-a sharîa-governed 
space-as a forestate to what it probably 'plans' to extend to other parts of the country. Its capture and brief administration of Gwoza apodictically demonstrates this, where it hoisted its flag and announced the headquarters of its caliphate (Azama 2017: 83; MacEachern 2018: 155). Boko Haram's reference to a caliphate expressly underscores that it wants an exclusive rule based on sharî $a$ and an Islamic identity. Accordingly, Michael Ibanga and James Archibong (2018: 147) state that "Boko Haram has established a strong administration based on Islamic Law. During the duration of its occupation of Mubi town in Adamawa State, ten people were tried and convicted of looting and other offences and had their hands amputated."

In the light of the foregoing, to deny as Nigerian President Muhammadu Buhari (2015) has done that the ideology of Boko Haram is influenced by Islam, seems patently incorrect and is, in fact, provocative. The present study is provoked by the inauguration speech of President Buhari delivered on 29 May 2015. Although the speech touches on many issues of national life, a significant space is given to security challenges especially those posed by Boko Haram. Since July 2009, Boko Haram has not only continued to contest space with the Nigerian government but has also taken over some spaces where it has raised its flag and declared independence. Past administrations of the Federal Republic of Nigeria - Presidents Musa Yar'Adua and Goodluck Jonathanmight have tried their best in either curtailing or exacerbating the occupation of swathes of spaces in the North-eastern part of Nigeria, especially in Borno, Yobe, and Adamawa states, by the group. The line that President Buhari treads in the speech under review is that Boko Haram is not only "mindless" and "ungodly" but also "un-Islamic." These comments are critical in understanding and contending with the group, for, the first is emotive-being an ethical judgement that might not have added much to the meaning and essence of the group — and the second and third are theological and ideological—which provides the cannon fodder for its persistence and motivation. It is the second that President Buhari has denied, which is the thrust of this chapter.

The argument here is that Boko Haram draws strong ideological inspiration from its reading of Islam, and to deny it is to misunderstand the group altogether, the consequence of which is that wrong diagnosis can result in wrong prescription and administration. On the other hand, to accept that its ideology is, at least in its own estimation, 'Islamic' would enable counter-narrative processes, which have the potency of blocking recruitment, de-radicalisation, and possible resurgence in the near future. Although the securitisation process is important as the Nigerian and other regional governments are trying to intensify anti-terror efforts, it is mainly to reclaim the contested spaces from those who have established an illegal sovereign government. To achieve the 
aims of this chapter, we shall conceptualise ungoverned spaces or alternatively governed spaces from global and Nigerian contexts, analyse Buhari's speech as it relates to our leitmotif, and finally emphasise the ideological implications involved, arguing that counter-narrative processes cannot be ignored as they are effective responses to ideologically-induced terrorism.

\section{2 Conceptualising Ungoverned Spaces}

The concept of 'ungoverned spaces' is sly and controversial. It is so because many definitions proffered to encapsulate its contents have either failed woefully or succeeded only partially. One question is whether there can be actual ungoverned spaces. We are poised to think that there is no such space that remains ungoverned in the physical or in the orbital. Put differently, every available space, even at interplanetary level, is governed by some persons or forces who dictate their affairs rightly or wrongly. These persons or forces hold the belief that they are legitimately, even if not legally empowered, to exert authority over the spaces under their control. An attempt to oust them makes the space a contested one. In the interim, the contested space is governed by an alternative force. This line of thinking is what leads us to the concept of 'alternatively governed spaces', since there is no actual absence of control over the space.

The Foreign and Commonwealth Office (2014: 1) argues that it is not just that there are no such spaces called ungoverned spaces but even "the very existence of truly 'ungoverned space' is questionable." Six reasons are adduced for this position. One, the term does not take into cognisance the variations that practically exist between and within states. Two, it is state-centric, that is, it does not recognise the fact that it is not only the state that exists as a governable space. Three, it does not envisage the fact that other forms of government other than the state such as monarchy or sectarian government exists: these are in fact forms of government that exercise enormous power and authority, which Western theories may not recognise within a state-oriented structure, but are essentially are alternative governments in their own right. Four, it is also generally assumed that the so-called ungoverned spaces are high risk areas that produce violence or terrorism. This may not always be the case because: consider cyberspace, for example, as a form of ungoverned though not strictly physical space, acquired by terrorists to operate effectively. Five, much attention is drawn towards weak or failing states without a corresponding consideration that the 'strong' states may not be insulated from the incidence of ungoverned space. In fact, terrorists are more interested in spaces 
that have modern facilities that can ease their operations rather than vast expanse of 'barren' spaces that can make them ineffective. Finally, six, it does not empirically demonstrate, as it is commonly theorised, why many of the terrorist operations are in advanced states rather than developing or fragile ones which are majorly conceived as less-governed, ungoverned, or mis-governed (Foreign and Commonwealth Office 2014: 1-2).

Michael Clark and Renad Mansour argue that what is at stake in ungoverned space discourse is "spaces of contested governance and mis-governance" (2013: 2). Working with data generated from Syria, Clark and Mansour maintain that the logic of ungoverned space is unsound for the simple fact that spaces termed ungoverned are actually either disintegrated or lack the presence of governance at all, and are now being alternatively governed. It is the alternatively governed spaces that are indeed spaces of contested governance and mis-governance. They note that since there are no absolutely ungoverned spaces, it is better to talk about space voluntarily ceded, which falls within the ambit of mis-governance, and space which is not ceded voluntarily, which can be referred to as contested governance. In the latter case, the state only performs its normal governance functions where other actors are not in control, but contest with non-state actors in the performance of governance functions. Spaces of contested governance, just like the state, strive to perform its normal responsibilities and non-state actors struggle to do the same. In reality however, since the state does not voluntarily cede its space, the idea of misgovernance readily explains the reason for contested governance.

Since governance is pivotal to space ownership, Clark and Mansour insist that the fundamental questions to ask should be: "who is governing, how are they governing, and what are the consequences of this mode of governance?" (Clark and Mansour 2013:3) This does not obviate the contest, for, as they hold:

In the case of spaces of contested governance, this core problem-how the space is governed and by whom-takes on added significance. By definition, in such areas it is frequently unclear who is governing; often, even when the identity of the dominant actor is established, the manner in which governance is being implemented and its consequences remain opaque.

CLARK AND MANSOUR 2O13: 3

According to Clark and Mansour, contested spaces are 'safe havens' for nonstate actors that have come to occupy them. Ilija Djugumanov and Marko Pankovski (2013: 9) succinctly define 'safe haven' as a "space for operational activity," spaces where non-state actors can galvanise and mobilise forces for 
expansionist purposes. From there, they "are able to establish themselves, consolidate, plan, organise, fundraise, recruit, train, and operate" (Clark and Mansour 2013: 3). Safe havens are spaces governed by non-state actors, which may also be contested.

Jennifer Keister (2014) like other scholars who have contributed to ungoverned spaces discourses focuses on either their legal or political economy dimension. This is understandable because their thrust is towards policy formation on how best to either manage or eradicate ungoverned spaces. The more prominent factor, which is political economy, does not answer the thorny question that borders on why there are ungoverned spaces in states that are well governed, which have modern military soft and hard wares. It does not also proffer solution to the radicalisation of those (especially terrorists) who believe that such spaces are their portion where their form of independent government should exist. For radicalised groups and individuals, ideological bent of mind is more important than political economy of those they conceive as enemies of their ideology. The question is: why, in spite of favourable political economy will people choose to operate a separate space from the state? The examples of Boko Haram in Nigeria and Islamic State of Iraq and Syria (ISIS) point to ideological suasion for deliberately creating alternatively governed spaces. Why would a British Muslim fly to fight on the side of ISIS rather than Britain? Or, why would Boko Haram raise its flag and set up an alternative government in areas it has conquered within and around the Nigerian borders? The obvious reason is theologically ideological, and not political economy as many have argued. It is this vacuum in literature of ungoverned spaces this paper fills with particular reference to Boko Haram and its ideology being denied by President Buhari. But before analysing President Buhari's speech, it is pertinent to give a brief historical development of Boko Haram.

Many opinions have been canvassed as regards the evolution of Boko Haram, a group which calls itself Jama'atu Ahlis Sunna Lidda'awatiwal-Jihad meaning 'Association of Sunnīs for the Propagation of Islam and for Holy War' or 'People Committed to the Propagation of the Prophet's Teaching and Jiha ad'. Literally, boko in the Hausa language means 'book', while harām in Arabic means 'forbidden'. It is the combination of these two words that form Boko Haram, a nickname given to the group by the people of Bauchi State and popularised by the media, because of its preaching against Western education. For the group, Western education is forbidden for a true Muslim because of its corruptible 
contents and inferiority to an Islamic education (Igboin 2014a). The group believes that Islamic education should hinge on the teachings of the Qurann and the sunna (practices of Prophet Muhammad). But along this line, however, Boko Haram has clarified this perception: it argues that it is not against Western education exclusively, but Western culture more broadly. According to Boko Haram,

Boko Haram does not in any way mean 'Western education is a sin' as the infidel media continue to portray us. Boko Haram actually mean 'Western civilisation' is forbidden. The difference is that while the first gives the impression that we are opposed to formal education coming from the West, that is Europe, which is not true, the second affirms our believe [sic] in the supremacy of Islamic culture (not Education), for culture is broader, it includes education but not determined by Western Education. In this case we are talking of Western Ways of life which include: constitutional provision as if [sic] relates to, for instance the rights and privileges of Women, the idea of homosexualism, lesbianism, sanctions in cases of terrible crimes like drug trafficking, rape of infants, multiparty democracy in an overwhelmingly Islamic country like Nigeria, blue films ... alcohol and many others that are opposed to Islamic civilisation.

quoted in THURSTON 2018: 11

This modification became necessary because the group wanted to firmly root its origin and cause in an Islamic theology and ideology posited as oppositional to that of the West.

A further indication of this modification can be gleaned from the name it calls itself, namely Ahl al-Sunna wa-l-Jihād. As Alexander Thurston (2018:11) analyses it, this name means that the group claims that it is a model of the Prophet's teaching and the authentic Muslim community. In addition, the group also claims that it is in the right position to dictate the 'true state of the religion', and further emphasises their Sunnī ideology, which is grounded in Salafism. No matter the name by which the group has called itself, the fact of its antagonism towards the West is established, and in fact, legendary among radical Muslims in the northern part of Nigeria. Paradoxically, while there is much hatred towards Western civilisation, these Muslims have continued to utilise the products of this civilisation to prosecute their religious agenda. Indeed, after analysing many of the speeches and sermons of Boko Haram's founder Mohammed Yusuf, as they touch on the stance of Boko Haram with Western values and modernity, Edlyne Anugwom (2019: 212-213) argues that Yusuf was mostly ambivalent in his handling of this issues. Yusuf tended to 
oscillate between total rejection and implicit acceptance. More critically, Yusuf had sometimes borrowed from Western political ideologies and movements in his organisation and execution of his group's agenda. The weapons he used and which the group continues to use today are products of Western technology and culture.

The most popular version of the evolution of the group is that it was a political outfit or instrument of the former governor of Borno State, Ali Modu Sheriff, who in 2002 used it as support for his political ambitions. This school argues that it was the disagreement between the group and the governor that led to its radicalisation. This school views the emergence of the group as politically motivated. Marc-Antoine de Montclos (2014: 5) for instance, argues that even though Boko Haram as an Islamic group has a religious background, it is "political in nature because it contests Western values, challenges the secularity of the state and reveals the corruption of a system that relies on a predatory ruling elite." The immediate past governor of Borno State, Kashim Shettima, while supporting the 2002 thesis, argues that the Boko Haram started as a group known as the Taliban, with the codename Kandahar, a name borrowed from Afghanistan. The group aimed "to freely worship as an Islamic body that sought to commit members to spiritual devotion to Allāh" (Shettima 2015). Of course, this was the grooming stage of what would later become a violent group.

In 2004, the group attacked police formations in Bama and Gwoza, and had to be repelled by soldiers. There was another sudden attack in 2007 in Kano, which also resulted in inviting the soldiers to quell the group. By 2009, the clash between the Boko Haram and the police once again resulted in the full militarisation of the group, following the order of Mohammed Yusuf who called for jihād. While the opinion of this school is legitimate, it does not unravel the historical facts behind the ideological development that encouraged this metamorphosis into a radicalised organisation as Boko Haram has come to be known today. After all, Shettima (2015) agrees that his "chronicles of the Boko Haram [were] based on some respected accounts" but in fact, the political narrative has been largely associated with Western media, which in the course of time became an overarching narrative of the motif of the group.

Monica Emmanuel (2016) gives the impression that the emergence of Boko Haram can be viewed in the light of the politicisation of religion, a phenomenon that is widespread in Nigeria. This argument of politicisation goes even further to say that the group was carefully orchestrated to frustrate the administration of former president Goodluck Jonathan, a Christian from the southern part of Nigeria. In other words, Boko Haram was a militant resistance group against the change of political power in the Nigerian federal structure, 
often more than not dominated by the Muslim North. She posits that even though religion has a role to play in the activities of the group, it is mostly a tool of mobilisation. For her, Islam helps the leadership of the Boko Haram to easily convince poor members of society to enter its fold, and thereafter radicalise them. As true as this may sound, it does not address the historical and ideological trajectory of the movement. Her analysis basically countenances the conflict and insurgency that resulted long after the group had been in existence.

In another vein, Scott MacEachern (2018:3) argues that an eclectic approach to understanding the origin of Boko Haram is in order because radical groups usually have different motivations. This is not to ignore the religious background to the emergence of the group as "religion is certainly a central element in any comprehensive understanding of Boko Haram" (2018: 3). MacEachern observes that there are religious, political, social, military, gendered, economic, and cultural ways of making sense of the group. As an archaeologist, he started his investigation by looking at the history of the cultural and human landscapes involved in the emergence of Boko Haram. Emphasising instead the military and theological outlook of Boko Haram, Sadau Azama (2017: iv) argues that the group was established in 2002 with the sole aim to "establish an Islamic state and institutionalise Sharia law in Nigeria, particularly the northeast region." As Azama notes, a key motivation was the establishment of a caliphate with distinctive Islamic law and enforcement over the 'corrupted' Sokoto caliphate that has embraced Western civilisation.

Rather than 2002 as the year of origin of Boko Haram, S.O. Anyanwu (2012), Abdulkareem Mohammed (2010), and Shehu Sani (2011) have traced the nascence of the group to 1995. According to them, Boko Haram started in 1995 under the leadership of Abubakar Lawan from Kano as the Sahaba group. When Lawan left for further studies at the University of Medina, he handed over to Yusuf. Yusuf made allegations of corrupt practices against the founder and senior clerics "in order to subdue them. They gave in to his blackmail and he took over control" (Mohammed 2010: 40). Soon after, Yusuf changed the doctrines bequeathed to him and began to form a separatist movement against the establishment. Sani (2011) notes that Yusuf did not hide his puritanical, fundamentalist, and theocratic vectors, which he carved after the thirteenth century controversial scholar, Taqī ad-Dīn Aḥmad ibn Taymiyya, a prominent personality in Salafi thought and who was an uncompromising defender of Sunnì Islam. Ibn Taymiyya believed that the Qur'ān and the sunna were sufficient for the guide and salvation of Muslims. He also thought that the four prominent schools of jurisprudence had become sectarian and unhelpful, particularly because of the influence of Greek thought, logic, and Șūfi mysticism. Consequently, he strongly advocated a return to the Qurān and sunna as 
exemplified by the Prophet Muhammad in Medina. It is this religious persona that Yusuf named his mosque after in Maiduguri: the Ibn Taymiyya Markaz (centre). Yusuf made ample references to Taymiyya's teachings and ideological bent as the basis for a quintessential umma (Islamic community), and frequently drew moral boosts and authority from his teachings and style (Salkida 2012; Thurston 2018). Yusuf further drew inspiration from ibn Taymiyya's austere lifestyle, which was notably uncommon for most religious and political leaders in northeast Nigeria (Smith 2015). As Ahmad Salkida (2012) concludes "the root cause of the [Boko Haram] conflict is ideological in nature" contrary to Ahmad Murtada's (2013:5) position that before 2002 "the group had no ideological agenda," while Shettima (2015) maintains that it had "misguided ideologies." Salkida elaborates his argument thus:

Clearly, there's huge and frightening degree of unemployment in Northern Nigeria. But the real fuse that drives this level of terror is with the sect's doctrinaire and ideologue. What we are dealing with is a growing Islamic ideologue that greatly appeals to young people. The doctrines that the leaders of the Boko Haram founded their sect cannot be separated from the global jihad movement that exploits the widespread suffering, resentment, and anger in the Muslim world.

SALKIDA 2012

Before 2002, Yusuf had become prominent in Borno state as he was a member of the state's committee on the implementation of sharîa. In his own capacity as a religious preacher with an ideology and agenda for an alternative state, Yusuf had also established "laginas (departments), had a cabinet, the Shura, the Hisbah, the brigades of guilds, a military wings [sic], a large farm, an effective microfinance scheme, and late Yusuf played the role of a judge in settling disputes. Each state had an amir (leader) including amirs in Chad and Niger that gave account of their stewardship to Yusuf directly" (Sani 2011: 27-28). Yusuf was already administering a state-like structure based on sharîa within the fringes of the Nigerian state or what Thurston (2018: 80) calls "an imaginary state within a state." This bordered on a social justice and welfare scheme which enticed the poor masses into his Ibn Taymiyya Markaz centre in Maiduguri. In fact, before the start of the Boko Haram crisis in 2009, Yusuf could conveniently boast of five hundred regular members plus other admirers all over the place.

This was what attracted politicians to woo the group's support in order to win elections, hence its widespread political prominence. Yusuf's fundamentalist ideology led to a theocratic formation governed by puritanical rules, 
which he tried to extend to general society, especially in the North. Yusuf's rule became a prototype for his subsequent followers who established a government over conquered spaces or alternatively governed spaces. Shettima (2015) reveals that of the 27 local government areas in Borno State, 20 were at a time (between 2014 and 2015) under the control of Boko Haram where it "hoisted its flag and instituted quasi-administrative structures" and "declared a caliphate over captured areas" (Asiwe 2015). Although former Governor Ibrahim Gaidam (2015) of Yobe State countered his Borno counterpart that it was not true that "five local government areas in the two states are still under Boko Haram control," there is no disagreement about the intentions of the group to establish political control.

The teachings of Boko Haram under Mohammed Yusuf did not differ substantially from other examples of global Islamism, especially Salafism. Salafism is a fundamentalist-theological interpretation of the Qur'ān, and seeks to return Islam and Muslims to a vision of the puritan, pure religion that existed in Medina under the direct governance of Prophet Muhammad. Salafism derives from the Arabic etymology, salaf, meaning 'predecessors' (pl. asläf). The notion of al-salaf al-sahif, that is, 'pious predecessors', rose to prominence in global Salafism when it became obvious that there was a need to carefully select personalities and aspects of the early Islamic community to emulate in the course of reforming or advancing Islam in the contemporary world. Salafism emphasises literal interpretation of the Quràn and the sunna and according to Thurston (2018: 18), "Salafis narrowly interpret the Islamic injunction to worship one God, and they try to 'purify' other Muslims of alleged deviations in belief and practice." Thurston (2018: 109) tends to generally view Salafism as non-violent yet in the case of Boko Haram, he argues that Yusuf "tried to smuggle jihadist thought into a Salafi community that had originally been oriented toward non-jihädi Salafism." However, Abdulbasit Kassim (2018) notes that Thurston's averment cannot completely be true considering Yusuf's mentor, Salafi shaykh Ja'far Adam, who gave support to al-Qā'ida's global jihād against the 'far enemy' rather than the 'near enemy' of 'westernised' Nigeria.

Meanwhile, according to Stephen Schwartz (2012), neo-Salafis consider themselves as authentic followers of the asläf. Distinguishing between Salafi and neo-Salafi, he states: "The difference between the authentic aslä $f$ and the 'neo-Salafis' is defined additionally by things Muhammad and the asläf did not do. Muhammad is never known to have pronounced any Muslim an apostate, to cite the most obvious example, while the 'neo-Salafis' are avid to expel those of whom they disapprove from the worldwide community of Muslims." Indeed, Abubakar Shekau, leader of Boko Haram, emphasises neo-Salafi thought when he insists that Muslims outside Boko Haram are infidels. He denounces Saudi 
Arabia as "not Islamic" because it fails to strictly adhere to the teachings of Prophet Muhammad, and consequently it will "enter the Hellfire." Shekau has threatened that Boko Haram would soon perform the hajj and visit the Kaba in Mecca, ostensibly for 'cleansing' (Bodansky 2015: 38).

Adam had preached sermons supporting the use of violence to achieve Islamic goals when necessary. As a mainstream Salafi, Adam had predicted that "the jiha a d in Nigeria is coming, either they, the infidels, chase us out of Nigeria or we chase them out" (in Kassim 2018: 14). In fact, Yusuf himself confirmed the use of violence as a Salafist in some of his sermons before his death. According to him:

Our religion is Islam, our creed is the creed of the al-salaf al-sahil Ahlul Sunna Wal Jama'ah, and our manhaj [path] is jihäd. We believe that the Shariah is the only truth. The constitution is a lie it is Kufr [disbelief]. Democracy is a lie; it is Kufr. Working with the government that does not rule by Shariah is a lie; it is Kufr. Working with the security agencies is a lie; it is Kufr. For those who are ignorant, let them be aware that it is important for the Muslim to make hijrah from the institutions established by the tawaghit [idolatrous governments].

KASSIM 2015: 189

Kassim (2018:14) further reveals that as far back as 2001 when the Grand Mufti of Saudi Arabia Abd al-Aziz bin Abdullah Al Ash-Shaykh condemned the use of suicide bombs by Muslims, the Kano-based Salafi cleric Aminu Daurawa, who is at present the Commander General of Kano's Hisbah board countered the condemnation of suicide bombing and described "God as a suicide bomber." These precedents of preaching and ideological confirmations laid the foundation for the eventual ascendancy of Yusuf's jihädi-Salafi disposition. Kassim observes that when it mattered most, the mainstream Salafists became "jihädi revisionists" and subsequently "backtracked from the jihādi project" for which some of them were to later pay the supreme price.

Kassim (2015) espouses that jihädi-Salafism holds a theological belief that leans towards legitimising violence and violent rebellion, not only against infidels but also those Muslims who have even implicitly adopted a progressive form of Islam. Relying on Petter Nesser's definition of jihādi-Salafism as encapsulating "a revolutionary program of overthrowing unjust and un-Islamic regimes in the Muslim world, as well as irredentism aiming at expelling nonMuslim military presence and influences from Muslim lands" (Kassim 2015: 176), Kassim argues that a historical excursus into some Salafists operations reveals the fact that they are rarely quietist. Jihädi-Salafists have interpreted 
Islamic texts in ways that have justified the use of violence to carry out their operations: "Jihädi-Salafi doctrinal underpinnings on the legitimacy of jihäd as a tool to overthrowing the political rulers in the Muslim world developed from the interpretation that ruling by other than God's law is major unbelief" (Kassim 2015: 179).

In relation to Boko Haram, Kassim (2015) and Igboin (2020) point out the historical trajectories that developed and established jihädi-Salafism in the Nigerian Muslim society, from where Yusuf and Boko Haram, would eventually draw inspiration. In line with jihādi-Salafi ideology, Yusuf thought and also taught that secularism, democracy, and Western education, values, and civilisation should be replaced with Islamic education and sharîa law. He preached that democracy is intricately linked to secularism and thus to shirk or impiety, as according to him, secularism ousts God from society and human affairs. This can be seen in the mace which is the symbol of authority of a legislative assembly. In this sense, Muslims who bow to the mace are worshipping an idol, the penalty for which is death:

Parliamentarians and members of assemblies have combined between [sic] them making themselves gods and ascribing partners to Allāh. This is because their mace is their object of worship in various ways such as bowing to it, subjecting themselves to it, loving it and using it as a symbol of shirk [apostasy], as they do not pass any bill or make decisions without it. [Without the mace] such decisions are unacceptable and has [sic] no legal backing.

in MOHАMMED 2014: 16

In addition, Yusuf argued that though Western education is not bad in itself its contents must be censored. He insisted that Western education can be accepted to the extent that it does not clash with the Qurān, hadith and the sunna. Yusuf preached that Western geography, aspects of biology, geology and sociology are forthrightly forbidden for Muslims because they contradict the Qurān. "These branches of knowledge," according to him, "are not knowledge but full of unbelief. Even those studying it are aware if they are fair to Allāh, except they haven't studied Islam. If you have read geography, you'll know that in geography there is danger" (in Mohammed 2014: 18). He also condemned the 'big bang' theory, Darwinism, and "the law of conservation of matter and energy" because they oppose creationism (in Mohammed 2010: 52). Consequently, he urged true Muslims to "take up arms to purge our curriculum of heresy" (in Mohammed 2010: $5^{2}$ ). Thus 'heretical' and 'false' teachings are argued to be at the core of secularism, and democracy is the agent which 
secularism uses to impose the corrupt Western values on other nations of the world including Nigeria (Mohammed 2010: $56^{-57}$ ). In this sense, Boko Haram has it as one of its objectives to overthrow the vestiges of Western values and civilisation and replace them with sharîa law and education. Hence the group entrenched radicalised Islamic values in its agenda in conquered spaces in North-eastern Nigeria.

Like many religions Islam offers not just a religious belief system but a total way of life for the follower. This can clash with the idea of the compartmentalisation of life, which secular political structures, particularly the Western type, have promoted. Islamism, in vehemently rejecting this, enunciates and reiterates a structure that is essentially God-centric and clearly instantiated in divinely inspired sharîa law and praxis. While sharîa manifests in differing ways in Islamic communities around the world, it is also from this law that actions that have been viewed as violent or terroristic are drawn. In the contemporary West sharita and Islam generally are popularly associated with acts of terror and oppression.

Those who have studied terrorist groups have mostly ascribed their acts of terror to an ideology. For instance, Christopher M. Blanchard (2007) observes that al-Q̄āida's messages are ideologically situated and steeped in religion. Importantly, the idea that religion and politics are separable is uniquely Western: in religions like Islam the two worlds are intertwined. David C. Rapoport (1972), a renowned scholar of religion and terrorism, also argues that any attempt to deny religion as a key motivation for terrorism would mean that a proper process of arresting the trend might be forfeited. Accordingly, Rapoport (1984: 659) argues that until the rise of nationalism, anarchism and Marxism, "religion provided the only acceptable justifications for terror." Security analyst David Brannan (2007) corroborates the position that religion provides the cannon fodder for terrorist acts and as such religion is equally important for counter-terrorism, noting that religion provides the framework and organisational structure while theology legitimises action through interpretive science. Scholars such as Joshua Wright have pointed to Islam as a lived religion where certain "psychosocial religious factors" have made it especially prone to violent extremist expression (2016).

Hugh Segal and Serge Joyal (2011) suggest there are four stages believers pass through to become radicalised-though not all those who begin eventually complete the processes, this potentially transforms one from a 'seeker' to a 
'terrorist'. The first stage is Pre-Radicalisation, which has to do with life before the journey into radicalisation, that is, lifestyle, religion, social status, and education. The second is Self-Identification, which "involves the beginning of a religious seeking often following an economic, social, political, or personal crisis" (Segal and Joyal 2011: 10). The third is Indoctrination: "the individual wholly adopts jihādi-Salafi ideology and concludes that militant jihād is required to support and further the Salafist cause, and joins a cluster of like-minded individuals" (Segal and Joyal 2011: 12). The fourth stage they call Jihadization and designate as the critical stage that leads to planned violence: "members of the cluster accept their individual duty to participate in jihād, and begin planning for a terrorist attack" (Segal and Joyal 2011: 13). Segal and Joyal further reveal that the social, economic, and political reasons often cited as precursors of terrorism are secondary and insufficient. According to them, many terrorists and terrorist groups more often than not originate from the middle or uppermiddle classes rather from the poverty-stricken population. They argue that it is these upper classes that possess the wherewithal to mobilise and radicalise the poor people and not vice versa.

Rogelio Alonso et al (2008: 14) add that "a Jihādi Salafist ideology that promotes violence as a way to achieve the creation of a new caliphate as well as to recover territories that were once under Muslim rule is utilised to form a common bond." David Mandel (2002) also explains how religio-nationalist ideology and theology can motivate a wide-scale program of collective violence and counter-violence, citing the case of Usāma bin Lādin and President George Bush. bin Lādin's recourse to religious nationalism with al-Qā'ida worked and still works to rally support for other terrorist groups like Boko Haram who seek to establish religio-political control over states. Bouzerzour Zoubir (2014) notes that the action of jihād to carve or create an Islamic state is usually promoted by radicalised Muslims as religiously sanctioned because it is the will of God to implement sharīa globally.

We have gone this far to demonstrate the critical role religion-Islam in this context-plays in the radicalisation process that culminates in the kind of violence deployed by Boko Haram. In the case of Mohammed Yusuf, the former leader of the Boko Haram, he vehemently disagreed with his tutors and held stringent, extremist views about the Qurān and the implementation of a caliphate. Yusuf's "blistering speeches" were widely circulated which won him a large following across the cadres of his society. His group was made up of both educated and wealthy and poor and uneducated members of society, who appear to have been drawn to his teachings. Mohammed Kyari (2014: 14) sums it up as follows: "The message of Boko Haram, as outlined by Mohammed Yusuf, derived from and fed into the extant discourse and ideology of Islamism 
worldwide. Boko Haram narratives were framed within the radical Islamic discourse with which Mohammed Yusuf had become conversant ... The rejection of secularism, democracy, Western education, and Westernisation were the major planks of the narratives." The group itself has stated as follows:

We want to reiterate that we are warriors who are carrying out jihäd in Nigeria and our struggle is based on the traditions of the Holy Prophet. We will never accept any system of government apart from the one stipulated by Islam because that is the only way that the Muslims can be liberated. We do not believe in any system of government, be it traditional or orthodox, except the Islamic system and that is why we will keep on fighting against democracy, socialism and whatever.

AGBO 2011: 47

Olufemi Vaughan (2016) observes that the rise of Boko Haram was predicated upon the failure of the northern state governments to fully implement and abide by the ethos of sharita law since 1999. The resurgence of sharía in 1999 as the country returned to civil rule was hinged on the notion that it would produce a better society. The politicisation of shari $a$ and the crises that followed demanded a reform of Islam, which Boko Haram largely now represents, though in its extremity. This neo-Salafist outfit insistently preached hard messages of messianic revivalism that roundly condemned the northern Muslims, particularly the political leaders who Yusuf saw as compromisers with the idolatrous and corrupt systems entrenched by democracy. The haphazard implementation of shari $a$ and its complete failure and abandonment was frequently cited by Yusuf as an indication that a new order was needed to salvage Islam from further profanity. As a puritan, Yusuf expected Muslim politicians to live strictly moral lives, and the unconscionable corruption of politicians stimulated his Salafist spirit, which ultimately resulted in levels of "lethal violence unprecedented in Nigerian history" (Vaughan 2016: 219). Thus, contrary to popular expression, "Boko Haram's militancy did not cause Nigeria's political crisis ... rather, it reflects the endemic crisis of governance, especially in Northern states" (Vaughan 2016: 219). In other words, it was the situation in northern Nigeria that provided the impetus for Yusuf to practically and violently express his 'reform agenda'. Olufemi Vaughan (2016: 229) further elucidates this:

In the specific case of Boko Haram, its militancy does not simply reveal the extent of the crisis of national governance; it shows the eroding 
legitimacy of traditional Muslim rulers in Northern communities because of their essential role as a critical component of Nigeria's neopatrimonial state system. Furthermore, since militant Islamic groups such as Boko Haram have consistently exploited the pressure for sharia to stake their claims in Northern Muslim communities, the custodians of Nigerian state have had to confront a major constitutional dilemma between Nigerian secularism and a clamor for an Islamic theocracy.

The neo-Salafi orientation of Yusuf can also be seen in the religious philosophy of the Maitatsine sect in the 1980s, which many scholars have argued has many similarities with Boko Haram (Danjibo 2009; Walker 2016; Anugwom 2019; Igboin 2019). Maitatsine's threat to national security started before Nigerian Independence in 196o. Led by Mohammed Marwa, the sect erratically and violently propagated its doctrine of total rejection and eradication of Western civilisation. Marwa publicly denounced religious leaders before him as infidels because he considered them idolatrous, flirting with democracy and Western ideologies and cultures. His erratic nature came to a crescendo when he and his followers "denigrated Prophet Muhammad and had the popular ... phrase, 'may Allāh curse those who disagree with this (our) version'" (Anugwom 2019: 42). Marwa also rejected Isa (Jesus) as a prophet and regarded the hadith and sunna as illegitimate but emphasised the Qurānic verses he thought right for his ideology, especially his doctrine of millenarianism. He preached an imminent end of the world and the emergence of a redeemer who would lead God's army against the infidel and compromised Muslims. This ultra-fundamentalist revivalism could not accommodate Muslim leaders whom the group had already declared infidels, hence many of them were killed in the riots which preceded the war he prophesied. It was a strategy that Boko Haram would later adopt, which led to the "civil war" (Kassim 2018: 3 ) in the group, as we shall show below.

\section{$5 \quad$ Schisms and 'Civil War' in the Alternatively Governed Space}

The disagreement between Ja'far Adam and his protégé Yusuf has been interpreted in many ways, and the most prominent for us here is ideological inconsistency underlying the interpretation of Islamic texts in the context of the prevailing political situation in the country. The reality is that the disagreement resulted in the contestation of space and governance in a kind of schism. Yusuf moved on to create an alternative space where he felt his doctrines could better 
be served. Using the Ibn Taymiyya Markaz as his platform, Yusuf developed his theological and ideological teachings and mobilised a militant unit (Guitta and Simcox 2014). The confrontation with the security agencies and eventual extra-judicial killing of Yusuf by police in July 2009 introduced another phase in the development of Boko Haram. Abubakar Shekau, who succeeded the late Yusuf, resurged the group with violent attacks on the country. Shekau's unflinching Salafi orientation earned him several descriptions such as "crazy," "rabble-rouser," "deranged," "mad-man," "a brutal psychopath," "bloodthirsty lunatic" and the leader of "ignorants who are the antithesis of contemporary values" (Barkindo 2018: 53-54). Edlyne Anugwom (2019: 113) also describes Shekau as an "unstable character." Atta Barkindo (2018) argues that such perceptions about Shekau are merely emotive as they do not countenance the strategic and ideological prowess of Yusuf's successor. Shekau's successful campaigns, affiliation with international terrorist organisations, and funding of the group's operations are critical to properly situating the presence of mind of Shekau. While Barkindo's focus on Shekau's versality as a corporatist-strategist is important for policy-making and counter-terrorism, here we will focus on his religious philosophy and its underlying Salafist ideology.

Shekau's aversion for Western civilisation resonates in his attacks on perceived Western-style institutions and demonstrates continuity with the ideology of Boko Haram. This can be substantiated in the attacks carried out on schools, United Nations' buildings in Abuja, Nigeria's capital, and on police, the army, Christians and churches, and on moderate Muslims who criticised his religious credentials. Anugwom (2019: 114) posits that the schools are attacked because they represent Western civilisation, and the primary focus of attack on schools populated by Christian students testifies to this claim. The cases of abductions, such as the kidnapping of 276 Chibok school girls in 2014 and 110 school girls from Dapchi 2018, in Borno and Yobe states respectively, are quintessential. While the attacks on police and military formations and personnel are understandable, the attacks on Muslims raises questions as to the ultra-jiha adi-Salafi ideology of the group.

However, Shekau defends the group's attacks on Muslims on the grounds that he has credible information that such Muslims were working against the goals of Boko Haram. According to him, "even if he is a learned Muslim teacher, if we confirm that he exposes us to the government, his children will become orphans and his wife will become widow, in God's name" (in Anugwom 2019: 139). Boko Haram's killing of Muslims is defended on the basis of takfir, the accusation of apostasy levelled by the group against Muslims for allegedly practising impure, fake, or adulterated Islam. Adam was indeed likely one of the victims of Boko Haram: he was killed during prayer in a mosque in 2007 for 
allegedly opposing the group. Kassim (2018: 17) captures the rising extremism of Shekau thusly:

Shekau began to manifest signs of deviation on the issues of al-'udhr bil-jahl and takfir al-Muthlaq by declaring the entire Muslim population of Nigeria as infidels on the basis that they did not disbelieve taghut [the idolatrous government], their children still attended government schools, and they participated in democratic elections. Shekau's farthest level of extremism on the issue of takfir spurred his launching of an indiscriminate campaign of violence and confiscation of the wealth and properties of Muslims population that did not pledge allegiance to him.

Subsequently, Shekau would declare himself a Caliph over the territories taken, and demanded unalloyed loyalty, declaring as apostates those who had deserted the group or opposed him. Unquestioned obedience to his commands was expected from all members of the group including the highest echelons. Within the group, the Consultative or Shura Council is vested with the powers to deliberate and take decisions on issues to be implemented by the group (Sheehan and Porter 2014: 8; Omenma, Abada and Omenma 2020). According to Yossef Bodansky (2015: 14), "The Shura is Boko Haram's highest decision-making body, and the Amir ul-Aam cannot launch major operations, formulate strategy or issue communiques without the approval of the Shura." Shekau totally disregarded the decisions of the Consultative Council and superimposed his views or opinions onto it. In June 2012, Ansaru (or Jama' atu Ansaru Muslimina Fi Bilad al Sudan, which is translated as 'Vanguards for the Protection of Muslims in Black Africa'), emerged as a faction of Boko Haram, founded on their ideological diversion from Boko Haram's killing of fellow Muslims. Although Ansaru's activities centred on abduction of foreigners in Nigeria, it maintained its ideological disagreement with Boko Haram (Igboin 2014b; Faluyi, Khan, and Akinola 2019).

A further schism occurred in 2015 when a group headed by Abu Musab alBarnawi broke away under the name Islamic State of West Africa Province (ISWAP). As Kassim explains it the "transmutation from Boko Haram to IsWAP was fraught with newfound agreements at the Consultative Council on the issues of ideology and strategy as well as the persuasive efforts intended to discipline the megalomaniac idiosyncrasies and highest level of extremism of Shekau" (Kassim 2018: 19). Shekau and his lieutenants would later regard

1 Members of the Boko Haram's Consultative Council are not fully known except two that were listed by the Joint Task Force (JTF) to include Mamman Nur and Khalid al-Barnawi. 
al-Barnawi as an infidel, who "does not follow a sound doctrine from authentic Salafism" (in Kassim 2018: 21), and who "condones living in an un-Islamic society without waging jihād" (Anugwom, 2019: 196). It is reported that this ideological conflict led Shekau to assassinate some of his close associates (Vanguard 2017).

Although it has been argued that these sub-groups have reconciled and re-united, a claim Kassim (2018) seriously doubts, it has, however, shown the mosaic of ideological stranglehold that has run through the development and sustenance of Boko Haram. Even when there is division, it does not in any way suggest a reduction in the sub-groups' capacities to inflict violence, in fact, as the period of the 'internal' civil war shows (see Anugwom 2019), they were attacking in different forms and areas which make it difficult to strategically confront them. But the ideological leaning towards ultra-jihād-Salafism, no matter how it is interpreted and applied, is the cannon fodder of Boko Haram.

We have argued that Boko Haram, whether or not it is a sobriquet for the group that calls itself Jama'atu Ahlis Sunna Lidda'awatiwal-Jihad, is based on ultra-jihädi-Salafist ideology that has a long history in Nigeria. Even though the group has attempted to clarify that it does not condemn all aspects of Western civilisation as sinful, it has actually maintained an ambivalent posture. Western culture such as multi-party democracy, constitutionalism and any other aspects the group considers anti-Islam are declared harām, that is, forbidden. Sharita is presented as the absolute divine law that ought to guide human society, a body of law that is believed would purify all immoral behaviour in society. The absence of shari $a$, or its haphazard implementation and lacking support by the Nigerian Muslim leaders, is considered antithetical to the spirit and letter of the law, and this is blamed on the influence of Western democracy. However, sharita appears to have had the capacity to foster a democratic approach in post-colonial Nigeria. Even when the expanded sharita issue arose in 1999, it was vehemently argued that since the majority of northerners expressed their faith in sharía, as a democratic process would entail, opposition against it should be rested (Vaughan 2016: 173-174). This same ambivalence has trailed after the jihādi-Salafi ideology upon which Boko Haram is founded. In global Islam, Salafism has been interpreted in different ways, and different groups either hold to the quietist persuasion or jihädi-Salafi option, which Boko Haram has consistently aligned itself. The schisms and civil war within the group are borne out of ideological disagreement despite the fact 
that all the sub-groups have the belief in the establishment of sharita in the territory they are holding sway.

Rather than the popular argument that Boko Haram arose as a consequence of political economy factors prevalent in the North, however, we have argued that the group grew from an Islamist basis for the creation of an anti-Western caliphate. The desire to maintain alternatively governed space within Nigeria is part of the political history of the country. Nevertheless, while it is germane to intensify efforts towards addressing the socio-economic factors that might have been the immediate causes for the militancy of the group, and also deploy securitisation processes by the government and allied forces, more nuanced efforts need to be emplaced to deepen the understanding of the ideological diversity and influence that characterise the belief and operations of this group.

\section{References}

"Abubakar Shekau kills Boko Haram Spokesperson over Leadership Plot." 2017. Vanguard, 24 February. At https://www.vanguardngr.com/2017/o2/abubakar -shekau-kills-boko-harams-spokesman-leadership-plot/. Accessed o3/o6/2020.

Agbo, A. 2011. "The Plot to Stop Jonathan." Tell, 2 May.

Alonso, R., T. Bjorgo, D.D. Porta, R. Coolsaet, F. Khosrokhavar, R. Lohlker, M. Raustorp, F. Reinares, A.P. Schmid, A. Silke, M. Taarnby, and G. De Vries. 2008. "Radicalisation Processes Leading to Acts of Terrorism." A Concise Report Prepared by the European Commission's Expert Group on Violent Radicalisation Submitted to the European Commission on 15 May.

Anugwom, E.E. 2019. The Boko Haram Insurgence in Nigeria: Perspectives from Within. Cham: Palgrave Macmillan.

Anyanwu, S.O. 2012. "Boko Haram and Violence Halal: A Reversion of Values." In S.O. Anyanwu and I.U. Nwanaju eds, Boko Haram and Terrorism: Religious Conflicts and Dialogue Initiatives in Nigeria, Volume 2. Enugu: SNAAP, 1-14.

Asiwe, E. 2015. "Buhari vs Boko Haram." Huhu Online. At http://huhuonline.com// hunew/index.php/opinions/595o-editorial-boko-haram-and-buhari-s-state-of -denial. Accessed 29/o7/2015.

Ayegba, U.S. 2015. "Unemployment and Poverty as Sources and Consequence of Insecurity in Nigeria: The Boko Haram Insurgency Revisited." African Journal of Political Science and International Relations. 9:3, 90-99.

Azama, S.Z. 2017. "A Critical Analysis of Boko Haram Insurgency." Unpublished dissertation submitted to the US Army Command and General Staff College, Kansas, USA. 
Barkindo, A. 2018. “Abubakr Shekau: Boko Haram's Underestimated CorporatistStrategic Leader." In J. Zenn ed., Boko Haram Beyond the Headlines: Analyses of Africa's Enduring Insurgency. New York: Combating Terrorism Center, 53-73.

Blanchard, C.M. 2007. "Al Qaeda: Statements and Evolving Ideology." CRS Report for Congress, 9 July. At https://www.fas.org/sgp/crs/terror/RL32759.pdf. Accessed 18/06/2015.

Bodansky, Y. 2015. "The Boko Haram and the Nigerian Jihadism." ISPSW Strategy Series: Focus on Defense and International Security. 318, 1-47.

Botha, A., M. Ewi, U. Salifu, and M. Abdile. 2017. "Understanding Nigerian Citizens' Perspectives on Boko Haram." Pretoria: Institute for Security Studies Monograph Series. 196 .

Brannan, D. 2007. "Violence, Terrorism and the Role of Theology: Repentant and Christian Rebellious Identity," Doctoral thesis, University of St. Andrews. At http:// research-repository.st.andrews.ac.uk/ Accessed 22/o7/2O2O.

Clark, M. and R. Mansour. 2013. "After Pandora's Box Implications of Misgovernance and Contested Governance in Syria, and What this Means for NATO." Atlantic Voices. 3:4, 2-7.

Danjibo, N.D. 2009. Islamic Fundamentalism and Sectarian Violence: The 'Maitatsine' and 'Boko Haram' Crises in Northern Nigeria. Ibadan: Institute of African Studies.

Djugumanov, I. and M. Pankovski. 2013. "The Concept of Ungoverned Spaces Development and Perspectives." Atlantic Voices. 3:4, 8-11.

Emmanuel, M. 2016. Federalism in Nigeria: Between Divisions in Conflict and Stability in Diversity. Geneva: Globethics.net.

Faluyi, O.T., S. Khan, and A.O. Akinola. 2019. Boko Haram's Terrorism and the Nigerian State: Federalism, Politics and Policies. Cham: Springer.

Foreign and Commonwealth Office. 2014. "The link between 'ungoverned spaces' and terrorism: myth or reality?" At https://www.gov.uk/sitemaps/sitemap_4_2015-05 -o3To1.xml. Accessed 18/06/2015.

Gaidam, I. 2015. "Yobe Governor faults Borno Counterpart, says no LGs under Boko Haram Control." New Express, 27 July.

Guitta, O. and R. Simcox. 2014. Terrorism in Nigeria: The Threat from Boko Haram and Ansaru. London: The Henry Jackson Society.

Ibanga, M. and J. Archibong. 2018. "The Boko Haram Insurgency: Characterisation and Implications Under Municipal and International Laws." In J. Iyi and H. Strydom eds, Boko Haram and International Law. Cham: Springer, 137-153.

Igboin, B.O. 2014a. “'The President of Nigeria has no final say': Sharia law Controversies and Implications for Nigeria." Politics and Religion. 8:2, 265-29o.

Igboin, B.O. 2014b. "Boko Haram Fundamentalism: A Critical Metamorphosis." Claremont Journal of Religion. 3:2, 72-98. 
Igboin, B.O. 2019. "A Decade of Boko Haram Insurgency (2009-2019): Waging Peace through Social Action in Nigeria." In E.G. Konyana and D. Oguntola-Laguda eds, Religious Violence and Conflict Management in Africa: Phenomenological and Epistemological Engagements. Harare: Africa Institute for Culture, Peace, Dialogue and Tolerance Studies, 2-22.

Igboin, B.O. 2020. "Securitization of Boko Haram: A Philosophical Pessimism or Political Reality?" In K.O. Paramole, M.T. Salisu, and A. Johnson-Bashua eds, Interrogating Problematic Issues in the Humanities and Education: A Gedenkkschrift for Prof. Abdul-Lateef Mobolaji Adetona. Lagos: Department of Religions \& Peace Studies, LASU, 227-237.

Ini, E. 2013. "Bill Clinton Counters Jonathan, insists Poverty behind Boko Haram, Ansaru Insurgency." Premium Times, 23 February. At www.premiumtimesng.com/ news/122116-bill-clinton-counters-jonathan-insists-poverty-behind-boko-haram -ansaru-insurgency.html. Accessed o3/o6/2020.

Kassim, A. 2015. "Defining and Understanding the Religious Philosophy of jihädi-Salafism and the Ideology of Boko Haram." Politics, Religion and Ideology. 16:2-3, 173-200.

Kassim, A. 2018. "Boko Haram's Internal Civil War: Stealth Takfir and Jihad as Recipes for Schism.” In J. Zenn, ed., Boko Haram Beyond the Headlines: Analyses of Africa's Enduring Insurgency. New York: Combating Terrorism Center, 3-32.

Keister, J. 2014. “The Illusion of Chaos: Why Ungoverned Spaces Aren't Ungoverned, and Why That Matters." Policy Analysis. 766, 1-24.

Kukah, M. 2013. "Boko Haram Menace beyond Poverty" The Punch, 8th May.

MacEachern, S. 2018. Searching for Boko Haram: A History of Violence in Central Africa. New York: Oxford University Press.

Mandel, D.R. 2002. "Evil and the Instigation of Collective Violence." ASAP: Analyses of Social Issues and Public Policy. 2/1: 101-102.

Mohammed, A. 2010. The Paradox of Boko Haram. Kaduna: Moving Image Ltd.

Mohammed, K. 2014. “The Message and Methods of Boko Haram." In M.P. de Montclos, ed., Boko Haram: Islamism, Politics, Security and the State in Nigeria. Leiden: African Studies Centre, 9-32.

Murtada, A. 2013. Boko Haram in Nigeria: Its beginnings, principles and activities in Nigeria. Trans. A. Haq al-Ashanti. Kano: SalafiManhaj.

The National Bureau of Statistics. 2005. Poverty Profile for Nigeria.

Obinna-Esiowu, D. 2018. “5 Safest States in Northern Nigeria." PropertyPro, 1 November. At www.propertypro.ng./blog/5-safest-states-in-northern-nigeria/. Accessed o3/o6/ 2020.

Ogunfolu, A., U.M. Assim, and O. Adejumo. 2018. “Boko Haram: On the Road to Algiers?” In J. Iyi and H. Strydom eds, Boko Haram and International Law. Cham: Springer, 179-204. 
Omenma, T., I.M. Abada, and O. Omenma. 2020. "Boko Haram Insurgency: A Decade of Dynamic Evolution and Struggle for a Caliphate.” Security Journal. 33:1.

Rapoport, D.C. 1972. Assassination and Terrorism. Toronto: Canadian Broadcasting Corporation.

Rapoport, D.C. 1984. "Fear and Trembling: Terrorism in Three Religious Traditions." American Political Science Review. 78:3, 668-672.

Salkida, A. 2012. "Another look at the Boko Haram Philosophy." Premium Times. At http://www.premiumtimesng.com/opinion/106108-another-look-at-the-boko -haram-philosophy-by-ahmad-salkida.html. Accessed 14/o6/2016.

Sani, S. 2011. "Boko Haram: History, Ideas and Revolt." The Constitution: A Journal of Constitutional Development. 11:4, 17-41.

Schwartz, S. 2012. "Neo-Salafi' Fallacies and Muslim Reaction to Insults against Muhammad." Folks Magazine, 20 September 20. At http://www.islamicpluralism .org/2105/neo-salafi-fallacies-and-muslim-reactions-to-insults-against -muhammad. Accessed 22/o7/2020.

Segal, H. and Joyal, S. March 2011. "Security, Freedom and the Complex Terrorist Threat: Positive Steps Ahead." Interim Report of the Special Senate Committee on Anti-terrorism. At www.parl.gc.ca. Accessed 18/o6/2015.

Sheehan, M.A. and G.D. Porter. 2014. "The Future Role of U.S. Counterterrorism Operations in Africa." CTC Sentinel. 7:2, 1-8.

Shettima, K. 2015. "Democracy and Security in Northeast: The Borno Story." Daily Trust, 26 July.

Skitka, L.J. and E. Mullen. 2002. "The Dark Side of Moral Conviction." ASAP: Analyses of Social Issues and Public Policy. 2/1: 35-42.

Smith, M. 2015. Boko Haram: Inside Nigeria's Unholy War. London: I.B. Tauris.

Thurston, A. 2018. Boko Haram: The History of an African Jihadist Movement. Princeton: Princeton University Press.

"US Policy Toward Nigeria: West Africa's Troubled Titan." 2012. House Hearing, 112 Congress. US Government Publishing Office. At https://www.govinfo.gov/content/ pkg/CHRG-112hhrg74961/html/CHRG-112hhrg74961.htm. Accessed o3/o6/202o.

Vaughan, O. 2016. Religion and the Making of Nigeria. Durham: Duke University Press. Walker, A. 2016. 'Eat the Heart of the Infidel': The Harrowing of Nigeria and the Rise of Boko Haram. London: G. Hurst and Co. Publishers.

Wright, J. 2016. "Why is Contemporary Religious Terrorism Predominantly Linked to Islam? Four Possible Psychosocial Factors." Perspectives on Terrorism. 10:1, 19-31.

Yanay, N. 2002. "Understanding Collective Hatred." ASAP: Analyses of Social Issues and Public Policy. 2/1: 53-6o.

Zoubir, B. 2014. "Jihad as A Source of Terrorism: A Reality or Propaganda." Politics and Religion. 8:1, 93-115. 